\title{
Global Response in Lymph Nodes
}

National Cancer Institute

\section{Source}

National Cancer Institute. Global Response in Lymph Nodes. NCI Thesaurus. Code C159957.

Criteria for the response to treatment in lymph nodes, as a component of global response. 